\title{
A Field Study on the Determination of the Credit Card Users' Awareness of the Products/Services Offered with Credit Cards: Turkey Case
}

\author{
Yıldıray Kızgın ${ }^{1}$, Kübra Karaosmanoğlu ${ }^{1}$, Gülay Hız ${ }^{1} \&$ Tahir Benli ${ }^{2}$ \\ ${ }^{1}$ Muğla Vocational College, Muğla Sıtkı Koçman University, Turkey \\ ${ }^{2}$ Department of Business Administration, Kastamonu University, Kastamonu, Turkey \\ Correspondence: Yıldıray Kızgın, Mugla Vocational College, Muğla Sitkı Koçman University, 48000, Muğla, \\ Turkey. Tel: 90-252-211-3193. E-mail: ykizgin@mu.edu.tr
}

Received: July 23, 2013

Accepted: September 16, 2013 Online Published: November 15, 2013

doi:10.5539/ijbm.v8n23p13

URL: http://dx.doi.org/10.5539/ijbm.v8n23p13

\begin{abstract}
One of the most powerful tools in helping businesses so as to gain a competitive edge is to produce innovative products. In order to emphasize the importance of innovation, the credit cards market has been selected in this article. The innovative products and services offered to credit card users by the banks have been investigated and discussed in an academic debate in this field. A questionnaire applied to 402 persons as to determine the credit card consumers' use levels and awareness of credit card use in Turkey, and of an innovative product/service applications along with the credit cards.

The data conducted from this questionnaire, considering Garanti Bankası, Yapı Kredi Bankası, Akbank, İş Bankası credit card users, were processed in One-way Anova and Logistic Regression analysis. According to the results conducted, Akbank card users compare to other bank card users, in terms of product/service awareness, were noticed to have a higher level of awareness; income, gender, the variables such as duration and amount of card use were found to be statistically significant in terms of logistic regression models.
\end{abstract}

Keywords: innovation, credit card, credit card product awareness, logistic regression

\section{Introduction}

The perception of this situation by business enterprise is the shortening of product life-times, planning new and innovative products in the face of growing consumer demand, and reviewing of existing products and product differentiation. The developments of the banking sector and the structure of purchasing by using credit cards in accordance with the development in technology has recently transformed the credit cards into a financing tool used by everyone (Yilmaz, Budak \& Başaran, 2013). This is only possible with more detailed studies on routing the consumer behavior and awareness of the current users and potential buyers, in terms of and when determining variety of services and products that businesses offer. While the current products are differentiated in accordance with more detailed requirements of the consumers, it is tried to maintain the recognition/knowability of these products, and furthermore, it is tried to gain new users with the novelty and variety added to these products.

Both the growth in the transaction volume in the credit card market and the increase in the number of credit card users have made the intense competition among the banks in the credit card market. Along the lines of innovation in order to gain new customers and retain existing customer portfolio, the credit cards, offered only as a means of purchase and payment, have nowadays become exclusive products with different meanings (such as a source of prestige and status).

These days the consumer has, beyond the casual needs, turned to hedonic consumption forms, and has internalized and realized the credit card features which make it easy to reach these goals. For example, while imposing the idea that the pleasure and happiness are more influential than the abstract concepts and while emphasizing that these are things that can not be purchased with money the proficiency level of a credit card brand has been put forward through the ads for specific concrete values that can be purchased with money. Concerning the credit card features focused in the ads, the lounge service, food and refreshments, etc., that are 
presented to the card holder and user waiting at the airport for the flight time, and that make them feel privileged; roadside assistance service provided by his bank to the cardholder who needs road assistance. Similarly, free "travel insurance" owing to the travel tickets purchased with a credit card, may be given as examples for some of these types of products and services.

The services, provided by the banks along with the credit cards offered, has become a significant subject of marketing research in Turkey. While the limit of the credit card, his income and his spending trends, etc. of the card holder are significant in the selection of the credit card by the consumer in other countries. The privileged services that the individuals received at the airport, the installation of or discount for the bill of the product that they purchased, enjoying the valet parking discount, or free travel insurance that they received have become crucial factors for the choice of the credit card in Turkey. This indicates that what is preferred by the consumer is not the credit card itself, but the choice of products and services offered along with the card.

In terms of creating new markets and maintaining the existing market share, and competition in the credit card market, development of "the innovative products and services" by the banks, concerning the credit card market, by taking into account the target group, constitute the basis for this research.

It has been noticed that "the credit card features", provided for diverse audiences by the banks after diversified, are not known or fully understood by the cardholder. Given this situation, despite the increased number of credit card users, the potential costs of the credit card features promised by the banks have decreased. This also affects the brand loyalty, implemented by the banks as a marketing strategy. Hence, by this and other studies to be carried, it will be possible to reach answers to the questions; can the increase rates of the number of the banks' brand loyalty credit card consumers? Or the new consumer gains with the credit card features be monitored more concretely?

The main objective of this study is to determine the level of consumer awareness and usage of credit cards and complementary innovative products and services offered to consumers in the credit card market in Turkey.

There exists no concrete study in this subject field, which increases the significance of the subject. The developments of such credit card products and services in Turkey is observed to be a result of competition among the banks. When considering the developed countries, it is seen that there is a competition where the banks provide the business customers with discounts only, by means of the strategic partnership that the banks established with the business. However, due to the development of the credit card use, for the business that want to gain a share those that want to increase their share, or those that want to maintain their share in the market, it seems possible to develop such credit cards, products and their services.

\section{Conceptual Framework and Research Hypothesis}

One of the most crucial decisions of marketing management is identification of target market and determination of the marketing mix for the target market. The purchasing attitudes and the choice of consumers and the changes experienced under competition conditions as a forcing power has always directed the business to make a change. Thus, the business enterprise adopts innovations covering the different perspectives on consumer satisfaction in the market. Marketing strategy of the marketing management, in the position of applying these innovations, strengthens the brand identity and value then guarantees the effectiveness and efficiency of marketing activities. As a result of these studies, the consumer perceptions of the brand is supported, and consumers are facilitated to decide to buy.

\subsection{Innovative Product and Brand Value Relations}

In a period when product differentiation is much more challenging, brand enables a business enterprise to ease its product differentiation. In addition to the actual physical differences of the product or service, brands also help to differentiate the subjective image that the consumers created in their minds (Yaraş, 2005). Differentiation of products and services, offered in conjunction with the credit card, by the banks is backed up with the demand created by the user, and it is distinguished by a new form life, and product specifications it offers to the consumer, as well.

When monitoring the developments considering consumers' expectations in product development, it is noticed that producing high quality products focusing only on technology is not enough anymore. Twenty years ago, designing a car and placing it on the market used to cover 14 years; however, today, this period has decreased up to a period of 3 years (Yayla, Yıldız \& Akyüz, 2009).

For the realization of a successful product development process, through all the steps, from idea to the presentation of the product to the market, full support of senior management, supplying adequate resources and 
support to R\&D activities, and supplying employees with the time and support required for participation in projects are extremely beneficial (Cooper, Edgett \& Kleinschmidt, 2003; Johansson, 2002; Kovanc1, 2004).

If a business enterprise adds new products to into new product series that will create technological and/or marketing synergy, this kind of diversification is named Concentric Diversification (Yükselen, 2012).

Using the brand's guidance both in new products and product differentiation is a crucial factor for new product marketing practitioners. In this respect, the brand makes a valuable means for the creation of the brand value and brand loyalty of the consumer perception.

The credit card, as the driving force and and facilitator of purchasing decisions, has been accepted as plastic Money and proved its existence. Credit card, as a means of making a purchase, can also be seen as a "retail banking" service as well. Banks can meet the consumers through credit cards (Torlak, 2002). It is well known that one of the most beneficial tools for the banks and other institutions providing credit card and card services in order to expand their card service markets and increase the size of credit card spending. It is to increase, more specifically, the size of credit cards and such applications with more developed products and services; to diversify the card and its service area so as to meet the expectations of the consumer's interest, and to promote the use of cards effectively.

The markets should be measurable, reachable, distinguishable, and large enough so that new and/or innovative products can be successful in the target market. By determining the needs of different consumer groups based on current market segments, by creating different marketing programs for each group, consumer demands and needs will be met better. The orientation will be provided towards profitable and attractive market segments; promotional messages and tools will be more effective and efficient, and changes in the market will be monitored better (Mucuk, 2001). The most significant element of the expansion process of innovation is communication. A business can not only reach the communication to target markets through the promotion mix elements but also monitor it through the person to person transfer of the level of satisfaction concerning the innovation (Odabaşı \& Barış, 2003). Consumers prefer the business applications intending to spare time to them (Zaltman, 2003).

A result of the intense competition in the credit card market, banks have started adding new features to their credit cards. These are: loyalty programs (such as the target points), money-back programs (such as discounting some of the shopping amount) and programs, such as community cards. Adding new features to the credit cards, especially by leading banks, becoming a multi-brand in cooperation with a variety of brands, and providing installments of card spending, have given rise to the intensification of competition in this area, and this competition has led the banks' attention to their customer relationships.

\subsection{Influence of Brand Value, Awareness over Purchasing Decision and Hypothesis}

Brands and products represent the company to which they are attached, and reflect the value of a brand. A trademark, beyond being just a logo or a name, expresses and reflects the feelings and the thoughts of institutions about the products. Everything brand-specific, more than just the form, structure and packaging, is contained in the concept of property brand (Aktuğlu, 2004).

Brand value is defined as a set of, linked to brand name and symbol, provided by products and/or services for the firm's customers, which increase or reduce the value of assets and commitments (Aaker, 1991). Increasing the value of the brand depends on the reception and implementation of product pricing, distribution and promotion decisions in line with the brand's goals and objectives so as to form a synergy. The high brand value that shows it has been successful in the region, country and the world (Elitok, 2003).

Consumers are affected in the purchase decision-making process and brand preference realization process by the brand value. Brand value creates a commitment in the same proportion as it reflects the consumers' wishes and expectations. The most crucial factor that the consumers prefer one brand to others is that they are affected emotionally and cognitively.

Furthermore, many factors-such as the nature of consumer demand, perception of the brand characteristics by consumers, image of companies producing the brand, marketing strategies and so on-determine brand preference (Aktuğlu \& Temel, 2006).

The primary aspect of a product or service reaching the consumer is the symbol or logo of the brand which is integrated with the brand. Logo is the face of the brand. The consumer first meets the brand's logo, and then sees the shape or functionality of the brand, in terms of brand-logo relationship, being different from competitors in selecting the color is extremely valuable. His encounter with this symbol familiar to consumers in retail 
environments race against time allows the consumer to decide more quickly. After a certain experience, the consumer begins to associate a certain brand with himself, and brand loyalty arises (Leblebici, 2009).

That credit card brands are diversing, and that the features which they possess turn towards more specific areas and towards consumers with more diverse qualification, make consumers willing these groups of products and services. Credit cards, the banks offer to consumers with different names and more detailed (disaggregated) features, are the key indicator of the brand's commitment, as well. The Consumer take an unwilling and uninterested position against other alternative cards and presented products, due to more detailed features and the services provided by the credit card of his own bank. The individuals' level of awareness and use of the products and services along with the credit cards have been tested by $\mathrm{H}_{1}$ and $\mathrm{H}_{2}$ hypotheses. These hypotheses will help to conduct answers to the comparative differences or similarities of the promotion efforts implemented by banks.

$H_{I}$. Card users awareness in terms of some of the products and services linked to their credit cards, is positively related to his/her banks.

$\mathrm{H}_{2}$. Card users' use some of the products and services linked to their credit cards, is positively related to his/her banks

Today's consumers make their purchase decisions on the basis of its relations with the manufacturer or service provider rather than product comparisons. Physiological satisfaction felt by the consumer may not be highly effective in creating brand loyalty or allegiance, for the consumers can easily opt for a more innovative and more affordable alternative. If psychological/emotional bonds between the brands and the consumers are not created, consumers will not opt for substitute products so quickly (Koç, 2012).

Businesses are required to establish a relationship, and to maintain it for a long-term by collecting a database of sociopsychological, demographic, psychographic characteristics of customers. In this way, they will create customer loyalty. This, in turn, has gained importance in the banking sector through Customer Relationship Management (CRM) process. The starting point of Customer Relationship Management is that today's customers have become more sophisticated than earlier customers (Savaşçı \& Tatlıdil, 2006). The effect of the overall credit card perception on the consumer satisfaction and loyalty has increased the consumer's satisfaction about the cards and consumer loyalty accordingly in parallel with the positive perception of the bank offering the credit cards. H3., H4., H5., H6. and H7. hypotheses test what extent do the banks guide the consumer groups appropriately in creating brand loyalty and customer loyalty? What extent do they use the demographic and socio-economic properties of these groups properly? By testing these hypotheses, it has been aimed to provide answers to questions about positions of the banks on account of making the credit card customers use of the products and services more efficiently and of increasing their product awareness, according to varying demographic characteristics such as sex, marital status, education level, income level and age.

$\mathrm{H}_{3}$. Card users awareness in terms of some of the products and services linked to their credit cards, is positively related to his/her gender.

$\mathrm{H}_{4}$. Card users awareness in terms of some of the products and services linked to their credit cards, is positively related to his/her marital status.

$\mathrm{H}_{5}$. Card users awareness in terms of some of the products and services linked to their credit cards, is positively related to his/her education level.

$\mathrm{H}_{6}$. Card users awareness in terms of some of the products and services linked to their credit cards, is positively related to his/her income.

$\mathrm{H}_{7}$. Card users awareness in terms of some of the products and services linked to their credit cards, is positively related to his/her age.

Businesses, offering their "new" products which are not so extraordinarily different from one another, send their messages through various channels to communicate more effectively with their customers or consumers (Odabaşı \& Oyman, 2007). The purpose of these messages, transmitted through promotion mix elements, is not only to redirect the consumers to a buying decision but also to create a relationship in long-term, and to establish brand loyalty by strengthening brand value and awareness. The consent of innovations made is only possible with the consumer acceptance (Schiffmann \& Kanuk, 2007). Hence, while differentiating their credit card characteristics, many bank have started their evaluation with the communication they will establish with different card users in varying market zones (La Tour, La Tour \& Zinkhan, 2010). 
H8. and H9. hypotheses test whether the lifetime and usage (card expenditure amount) of the credit cards of the bank customers have any impacts on the awareness of products and services offered in conjunction with the credit cards. In this way, it has been aimed to determine whether the banks' a long-term relationship with their customers would provide an increase in the customer loyalty, and whether, in accordance with the volume of transactions, this will have an impact on the awareness of the customers, who spend more on their credit cards, of the products and services supplied. The development of credit card users' awareness for products and services offered with the credit card is possible with the integrated marketing communication through which the brand value will better be evaluated by this way.

$H_{8}$. Card users awareness in terms of some of the products and services linked to their credit cards, is positively related to his/her card using duration.

$H_{9}$. Card users awareness in terms of some of the products and services linked to their credit cards, is positively related to his/her card expenditure amount.

\subsection{Literature Review}

It is expected to attract scholar attention, due to the fact that this is a pioneering study in its field in the world, As we could not take advantage of having a subject-based specific literature while conducting the search, this restricted the references on innovation and credit cards. This condition made the general literature about credit cards review a must.

The studies conducted on credit card use in Turkey are mostly limited with how influential the demographic characteristics of customers are on the credit cards choice of consumers, and are limited with the credit card use consciousness of the customers. For example, Yeniçeri \& Akturan (2007) concluded in their study that the unconscious credit card consumers spent till the last penny of their limits, they had the problem of repayment and pushed the price issue of products into the background.

The survey carried out by Cengiz (2009) reveals that demographic variables affect the probability of individuals to hold a credit card. The study conducted by Gökçen \& Kaya (2009) reveals that shaping the functions of the credit card in accordance with the demographic characteristics of its customers, increases the possibility of card use.

In their study examining the factors affecting the credit card use in Turkey, Tunalı and Taloğlu (2010), conclude that those who prefer the traditional investment vehicles such as gold are less prone to use a credit card. However, consumers who prefer treasury bills, bonds, valuable papers are more inclined to use a credit cards.

The findings of another study carried out by Ucal, Lou O'Neil \& Çankaya (2011), shows that among college students, the women in Turkey are less susceptible than men to use a credit card.

While Leblebici (2009) is stressing the contribution of the logo, which establishes the impact of the visual identity of a product's brand over consumer perceptions during purchase decisions, Scar (2005), stressing the importance of brand value in the creation of the marketing mix decisions, stated the effect on consumer perception of the brand. Aktuğlu \& Temel (2006) examined the factors that influence consumers' brand choice in terms of the factors influencing brand preference of the consumers.

In his study (2006) of "Determination of consumers' attitudinal differences for the brand equivalence according to the level of firms' financial performance" Karacan (2006), analyzed brand loyalty and brand image in detail, and successfully concluded that, in terms of brand value, they were successful in concrete products as well as in abstract products. Within an application measuring the impact of the installment application of the credit cards on the spending habits of consumers', Durukan, Elibol \& Özhavzalı (2005), put forward that consumers do not behave consciously while assessing their capacity of monthly expenditure in purchasing.

In their study "The Effect of the Banks' CRM (Customer Relationship Management) Strategy Applied in Credit Card Market on Customer Loyalty", Savaşçı and Tatlıdil (2006) examined CRM (Customer Relationship Management) process in the area of banking, and evaluated the strategies applied for customer loyalty in credit cards.

The number of surveys, in countries other than Turkey, examining the relationship between credit cards and the demographic characteristics of the people is increasing. For example, in a study conducted by Hyytinen \& Takalo (2008), it was determined that there exists a positive correlation between the income level and the conscious use of credit card tools by consumers, and using more than one mode of card payments affects has a positive impact on the conscious card use.

Another study conducted by Norvilitis, Osberg, Young, Merwin, Roehling \& Kamas (2006) investigated how 
the personal factors, personal debt tendency and the level of financial information explain the credit card borrowing level. As a result, it was found that there exists a significant level of correlation between the credit card debt and the number of cards used, and between lack of financial information and borrowing on credit cards. The findings of a survey conducted by Kim \& De Vaney (2001) reveals that there is a positive correlation between monthly income, the amount of assets and the number of credit cards and credit card debt.

In this study, they tried to measure the awareness of consumers/credit card users for products and services offered by credit cards. In this respect, consumer approach to credit card brand as a value of service was questioned. Examining the importance of the brand value in virtue of the decision to purchase, they highlighted the trends of the enterprises for the consumer perception in the process of differentiation of goods.

\section{Methodology}

\subsection{Study Design}

This study was based on the first hand data obtained from the card users in a questionnaire study conducted over the internet in order to determine the awareness of credit card users of some of the products and services provided by banks.

\subsection{Instruments}

The questionnaire consists of two parts: The first part involves questions on demographic, socio-economic, which the most frequently used card is, and use of this card. The survey questions in the second part aim to determine the card users' awareness about the products and services provided by the banks along with credit cards and the level of use. As the questions in the second part of the survey queried only for information about products and services offered with cards, a scale to measure a behavior form was not applied; and the responses (such as "individuals know the service or not know the service" and "use the service or not use the service") were evaluated.

\subsection{Sample and Procedure}

As of 2012, the total number of credit cards in Turkey is 54.342 .148 (BKM/ICC, 2013) pieces. From within the users of these cards; Garanti Bank (GAR = 16,7 (\%)), Yapı Kredi Bank (YKB = 16,4 (\%)), Akbank (APD =), and İş Bankası (ISB $=11,0(\%)$ ) have the biggest share in the credit card market in Turkey. Credit card users, holding brands of Adios, WorldCard, Axess, Fish, Max and Bonus provided by these banks to their customers, were identified as the main body.

384 credit card users were identified as the sample size for the study (with a margin of error of $5 \%$ and $p=q=$ 0,5 to 1.96). Within the last 6 months of 2012, the credit card holders living in various places all around Turkey were reached via e-mail, and were asked to participate in the survey. After the removal of deliberate wrong answers, those with no answer to critical questions, and those with duplicate answers, 402 questionnaire respondents were taken into account.

All card users were asked about products and services of banks, and their knowledge and the use of these products and services. The answers were collected within the form of options such as "I know, I use and/or I used", "I know, but have never used", "Never heard of it", and "This product/service is not about me, or my credit card does not have it. Afterwards, answers by a card user were evaluated in terms of products and services offered by the bank.

If he answered as "Never heard of it" or "This product/service is not about me or my credit card does not have it", it has been concluded that he is not aware of that product or service (not realizing $=0$ ); if he encodes one of the other two options in the form: "I know I am using/have used" or " I know, but I have never used ", this means that he is aware of the product or service (aware $=1$ ). This was applied to all the participants divided into groups in terms of products and services, the same as each other or different from each other, offered by four banks to their customers.

In terms of determining the level of use of this type of products and services by card users, answers for the questions with four multiple choices were taken into account. If he opts for the option, "I know I am using/have used" for a bank service, (Uses =1); If one of the other three options is selected, (not using $=0$ ) is encoded in the form.

In the next stage, user awareness scores were obtained through proportioning the user's awareness (the total number of products and services he is aware of) according to the answers he has given, to the total number of products and services the bank provided. The user scores were calculated through reapplying the same process for using scores. 
Awareness score $=$ number of awareness product or service $/$ total bank's product or service.

Using score $=$ number of using a product or service $/$ total bank's product or service.

\section{Research Results}

\subsection{Reliability and Validity Tests}

In order to determine the awareness and use of the new products and services offered by the banks to credit card users, the validity and reliability tests were conducted for the questions: "I know, I am using and/or I have used", "I know, but never used", "Never heard of it," and "This product/service is not about me, or my credit card does not have it", and the result is as follows:

The result of the test sample of all competencies were all from 0,5 to 1,0 in the range as Cronbach's alpha values is $(0,60<\alpha<0,80)$, it is possible to indicate that the scale questions were quite adequate in terms of reliability (Özdamar, 1999).

Table 1 . Validity and reliability analysis

\begin{tabular}{lcccc}
\hline & & KMO (Kaiser-Meyer-Olkin) & & \\
\cline { 3 - 3 } Bank & Credit card number & Measures of Sampling Adequacy & Item Number & Cronbach Alpha \\
\hline YKB & 132 & 0,728 & 13 & 0,782 \\
AKB & 51 & 0,632 & 17 & 0,857 \\
ISB & 114 & 0,610 & 15 & 0,808 \\
GAR & 105 & 0,621 & 13 & 0,781 \\
Total & 402 & & & \\
\hline
\end{tabular}

\subsection{Participants' Results}

According to the results obtained from 402 current survey, 70,9 (\%) of the participants are males and $29,1 \%$ are females. As for the distribution of credit cards by banks, Yapı Kredi Bank (YKB) holds 32,8 (\%), İş Bankası (ISB) holds 28,4 (\%), Garanti Bank (GAR) holds 26,1 (\%), and Akbank (APD) holds 12,7 (\%). It was seen that, of the participants, $61,7(\%)$ are married, and 38,3 (\%) are single; in terms of income level, 7,5 (\%) are "TL 1,000 or less", 16,4 (\%) are "TL1001-2000", $41 \%$ are "TL 2001-3000", 27,6 (\%) are "TL 3001-5000", and 7,5 (\%) are "TL 5001 and above" income group. Considering the age distribution of the participants, 6,7 (\%) are "24 and under", $42,5(\%)$ are "25 to $34 ", 29,9(\%)$ are "35 to 44", 18,7 (\%) are "45 to 54", 1,5 (\%) are "55 to 64", and $0,7(\%)$ are "65 and over". In terms of levels of education, of the participants, $3 \%$ are high school, 3,7 (\%) are vocational schools, 39,6 (\%) are faculty, and 53,7 (\%) are post-graduate. In virtue of duration of card ownership, $11,2 \%$ has used his card for "1 year or less", 45,5 (\%) for "2-5 years", 18,7 (\%) for "6-10 years", and 24,6 (\%) for "over 10 years". Considering the amounts of their spending by credit cards, 11,2 (\%) are "TL 250 or less", 20,9 (\%) are "TL 251-500", $9 \%$ are "TL 501-750", 23,1 (\%) are "TL 751-1000", and 35,8 (\%) are "TL 1001 and above" respectively.

\subsection{Awareness and Usage Results}

Table 2. Card users' awareness and use of bank products and services

\begin{tabular}{|c|c|c|c|c|}
\hline \multirow{2}{*}{$\begin{array}{l}\text { Bank Products and Services } \\
\text { Garanti Bank (GAR), }(\mathbf{N}=\mathbf{1 0 5})\end{array}$} & \multicolumn{2}{|c|}{ Awareness } & \multicolumn{2}{|c|}{ Use } \\
\hline & $\mathbf{N}$ & $\%$ & $\mathbf{N}$ & $\%$ \\
\hline Airport Lounge Service (GAR1) & 11 & 31 & 4 & 11 \\
\hline Travel Insurance services (GAR2) & 12 & 34 & 2 & 6 \\
\hline Shopping insurance (GAR3) & 10 & 29 & 1 & 3 \\
\hline Assistance Locksmith (GAR4) & 10 & 29 & 0 & 0 \\
\hline Plumber assistance (GAR5) & 10 & 29 & 0 & 0 \\
\hline Card loss / theft insurance services (GAR6) & 22 & 63 & 2 & 6 \\
\hline Use your cell phone as a credit card service (GAR7) & 23 & 66 & 5 & 14 \\
\hline Turkcell's mobile wallet service (GAR8) & 19 & 54 & 1 & 3 \\
\hline Glass breakage assistance (GAR9) & 3 & 9 & 0 & 0 \\
\hline Roadside assistance service (GAR10) & 10 & 29 & 0 & 0 \\
\hline Interruption and property of the card (GAR11) & 21 & 60 & 10 & 29 \\
\hline
\end{tabular}




\begin{tabular}{|c|c|c|c|c|}
\hline Personalized custom card design feature (GAR12) & 19 & 54 & 4 & 11 \\
\hline $\begin{array}{l}\text { Discount programs for products and services with the use of some of the card } \\
\text { (GAR13) }\end{array}$ & 29 & 83 & 21 & 60 \\
\hline \multicolumn{5}{|l|}{ İş Bankasi (ISB), (N=114) } \\
\hline Airport Lounge Service (ISB1) & 16 & 42 & 3 & 8 \\
\hline Travel Insurance services (ISB2) & 11 & 29 & 1 & 3 \\
\hline Installment Service (ISB3) & 22 & 58 & 2 & 5 \\
\hline Shopping insurance (ISB4) & 8 & 21 & 1 & 3 \\
\hline Personal Accident Insurance Services (ISB5) & 10 & 26 & 0 & 0 \\
\hline Valet Parking Service (ISB6) & 7 & 18 & 2 & 5 \\
\hline KGS / ETC Toll Service (ISB7) & 26 & 68 & 3 & 8 \\
\hline TEMA Foundation Card Help Services (ISB8) & 9 & 24 & 1 & 3 \\
\hline Card loss / theft insurance services (ISB9) & 20 & 53 & 1 & 3 \\
\hline $50 \%$ Discount on Parking at the Airport Service (ISB10) & 6 & 16 & 1 & 3 \\
\hline Use your cell phone as a credit card service (ISB11) & 23 & 61 & 3 & 8 \\
\hline Airport Shuttle Service (ISB12) & 7 & 18 & 1 & 3 \\
\hline Sea Taxi Service (ISB13) & 4 & 11 & 0 & 0 \\
\hline Interruption and property of the card (ISB14) & 25 & 66 & 8 & 21 \\
\hline $\begin{array}{l}\text { Discount programs for products and services with the use of some of the card } \\
\text { (ISB15) }\end{array}$ & 29 & 76 & 23 & 61 \\
\hline \multicolumn{5}{|l|}{$\operatorname{Akbank}(\mathrm{AKB}),(\mathrm{N}=\mathbf{5 1})$} \\
\hline Airport Lounge Service (AKB1) & 10 & 59 & 2 & 12 \\
\hline Yellow Line Information Service (AKB2) & 3 & 18 & 1 & 6 \\
\hline Tire Repair Service (AKB3) & 7 & 41 & 3 & 18 \\
\hline Installment Service (AKB4) & 14 & 82 & 0 & 0 \\
\hline Shopping insurance (AKB5) & 9 & 53 & 0 & 0 \\
\hline Valet Parking Service (AKB6) & 10 & 59 & 4 & 24 \\
\hline VIP Customer Line Service (AKB7) & 9 & 53 & 6 & 35 \\
\hline SMS Agent Service (AKB8) & 8 & 47 & 2 & 12 \\
\hline VIP CashPoint Service at CarrefourSA Super Markets (AKB9) & 5 & 29 & 1 & 6 \\
\hline Card loss / theft insurance services (AKB10) & 13 & 76 & 2 & 12 \\
\hline $50 \%$ Discount on Parking at the Airport Service (AKB11) & 8 & 47 & 2 & 12 \\
\hline Use your cell phone as a credit card service (AKB12) & 11 & 65 & 1 & 6 \\
\hline Bodyguard Security Suite Service (AKB13) & 1 & 6 & 1 & 6 \\
\hline Turkcell's mobile wallet service (AKB14) & 9 & 53 & 2 & 12 \\
\hline Airport Shuttle Service (AKB15) & 8 & 47 & 4 & 24 \\
\hline Interruption and property of the card (AKB16) & 9 & 53 & 9 & 53 \\
\hline $\begin{array}{l}\text { Discount programs for products and services with the use of some of the card } \\
\text { (AKB17) }\end{array}$ & 12 & 71 & 2 & 12 \\
\hline \multicolumn{5}{|l|}{ Yapı Kredi Bankasi (YKB), (N=132) } \\
\hline Airport Lounge Service (YKB1) & 25 & 37 & 10 & 23 \\
\hline Travel Insurance services (YKB2) & 21 & 31 & 3 & 7 \\
\hline Installment Service (YKB3) & 25 & 37 & 4 & 9 \\
\hline Shopping insurance (YKB4) & 17 & 25 & 0 & 0 \\
\hline Valet Parking Service (YKB5) & 9 & 13 & 1 & 2 \\
\hline Asistance Services (YKB6) & 20 & 30 & 5 & 11 \\
\hline $50 \%$ Discount on Parking at the Airport Service (YKB7) & 13 & 19 & 1 & 2 \\
\hline Use your cell phone as a credit card service (YKB8) & 20 & 30 & 4 & 9 \\
\hline Airport Shuttle Service (YKB9) & 7 & 11 & 1 & 2 \\
\hline Sea Taxi Service (YKB10) & 1 & 2 & 0 & 0 \\
\hline Roadside assistance service (YKB11) & 14 & 20 & 2 & 5 \\
\hline Interruption and property of the card (YKB12) & 24 & 36 & 11 & 25 \\
\hline $\begin{array}{l}\text { Discount programs for products and services with the use of some of the card } \\
\text { (YKB13) }\end{array}$ & 34 & 52 & 21 & 48 \\
\hline
\end{tabular}

According to the data in Table 2. It was seen that the most beneficial service that the banks provide their card 
users with awareness is the "credit card discount programs for some of the products and services with the use of the credit card." It was also seen that the highest rate of awareness (83\%) is of Garanti Bank card customers, İş Bank customers follows it with (76\%), Akbank customers with (71\%), and Yapı Kredi Bank customers with $(52 \%)$.

Again according to this data; services with the lowest rate that do not provide awareness is "Sea Taxi Service." the awareness determined for this service was at a rate of $(2 \%)$ of Yapı Kredi Bank customers, $(11 \%)$ of İş Bankası card users. İş Bankası customers have the second lowest rate of awareness at (6\%) with "Bodyguard security package service", and Garanti Bank card customers have the third lowest rate of awareness at $(9 \%)$ with "Glass breakage assistance."

Taken into account in terms of the services used; "Credit card Discount programs for the use of certain products and services" has the highest service usage rate, and in this regard, İş Bankası (61\%), Garanti Bank $(60 \%)$ and Yapı Kredi Bank card users (48\%) have the highest rates of service use, respectively. It has been seen that Akbank card users have the highest rate (53\%) of product or service use with "the card for interruption feature."

On the other hand, it was seen that Garanti Bank card users have never used four different services provided for them: "Glass breakage assistance," "Roadside assistance service," "Plumber assistance," "Locksmith Assistance," and "Plumber Assistance." It was also seen that "Sea Taxi Service" and "Personal Accident Insurance Services" of İş Bankası; "Installment Service" and "Shopping Insurance"of Akbank, and finally "Shopping Insurance" and "Sea Taxi Service" of Yapı Kredi Bank have no card users.

\subsection{One-way Anova Test}

One-way ANOVA test was performed to compare whether they are different in terms of awareness and use of products and services offered to them along with the cards.

First of all, for the implementation of the test, Normal Distribution Condition, which is one of the most fundamental assumptions of the test, must be realized. Skewness and kurtosis values of the variables can be used for this purpose. These values are required to be between " $-2<\mathrm{x}<+2$ " (Şencan, 2002). In the event of a breach, in this matter, according to Central Limit Theory, the data is assumed to suit the condition of normal distribution as the number of samples is over 40 (Diehr \& Lumley, 2002). In the study, it was observed that Awareness Score and Using Score variables, the difference between the means of which would be tested, were normally distributed (Awareness score Skewness $=0,421$, Kurtosis $=-0,576$; Using score Skewness $=0,628$, Kurtosis = $-1,614)$.

The results of one-way ANOVA comparing the scores of awareness and the use of card users according to the banks are given in Table 3 as below:

Table 3. One-way anova

\begin{tabular}{|c|c|c|c|c|c|c|c|}
\hline \multirow{2}{*}{ Awareness score } & \multirow{2}{*}{$\begin{array}{l}\text { Sum of } \\
\text { Squares }\end{array}$} & \multirow{2}{*}{ df } & \multirow{2}{*}{$\begin{array}{c}\text { Mean } \\
\text { Square }\end{array}$} & \multicolumn{2}{|c|}{ Levene's } & \multirow{2}{*}{$\mathbf{F}$} & \multirow{2}{*}{ Sig. } \\
\hline & & & & Statistic & Sig & & \\
\hline Between Groups & 1,213 & 3 & 0,404 & 0,813 & 0,487 & 7,116 & $0,0001^{* *}$ \\
\hline Within Groups & 22,617 & 398 & 0,057 & & & & \\
\hline Total & 23,830 & 401 & & & & & \\
\hline \multicolumn{8}{|l|}{ Using score } \\
\hline Between Groups & 0,123 & 3 & 0,041 & 8,640 & $0,001^{\diamond}$ & 3,204 & $0,023^{*}$ \\
\hline Within Groups & 5,080 & 398 & 0,013 & & & & \\
\hline Total & 5,203 & 401 & & & & & \\
\hline
\end{tabular}

${ }^{\circ}$ Not homogeneous variances ${ }^{*} \mathrm{p}<0,05 .{ }^{* *} \mathrm{p}<0,001$.

Difference of both Awareness Scores and Using Scores of the credit card users were significant at a 5\% error level. For this purpose, LSD test was used as the multiple comparison test according to "homogeneous variance" assumption; Tamhane's statistics were used according to the assumption that the variances are not homogeneous, and the results are given in the table below: 
Table 4. Awareness score ve using score according to banks multiple comparison (posthoc) results

\begin{tabular}{|c|c|c|c|c|c|}
\hline LSD & BANK(I) & BANK(J) & Mean Difference (I-J) & Std. Error & Sig. \\
\hline Awareness & YKB & $\mathrm{AKB}$ & $-0,162$ & 0,039 & $0,0001^{* *}$ \\
\hline \multirow[t]{11}{*}{ Score } & & ISB & 0,011 & 0,030 & 0,709 \\
\hline & & GAR & $-0,036$ & 0,031 & 0,244 \\
\hline & $\mathrm{AK}$ & YKB & 0,162 & 0,039 & $0,0001^{* *}$ \\
\hline & & ISB & 0,174 & 0,040 & $0,0001^{* *}$ \\
\hline & & GAR & 0,126 & 0,041 & $0,002^{*}$ \\
\hline & ISB & YKB & $-0,011$ & 0,030 & 0,709 \\
\hline & & $\mathrm{AK}$ & $-0,174$ & 0,040 & $0,0001^{* *}$ \\
\hline & & GAR & $-0,047$ & 0,032 & 0,140 \\
\hline & GAR & YKB & 0,036 & 0,031 & 0,244 \\
\hline & & $\mathrm{AK}$ & $-0,126$ & 0,041 & $0,002^{*}$ \\
\hline & & ISB & $-0,162$ & 0,039 & $0,0001^{* *}$ \\
\hline \multicolumn{6}{|l|}{ Tamhane's } \\
\hline \multirow[t]{12}{*}{ Using score } & YKB & $\mathrm{AKB}$ & $-0,036$ & 0,018 & 0,053 \\
\hline & & ISB & 0,022 & 0,014 & 0,120 \\
\hline & & GAR & 0,001 & 0,014 & 0,936 \\
\hline & $\mathrm{AK}$ & YKB & 0,036 & 0,018 & 0,053 \\
\hline & & ISB & 0,058 & 0,019 & $0,002^{*}$ \\
\hline & & GAR & 0,037 & 0,019 & 0,053 \\
\hline & ISB & YKB & $-0,022$ & 0,014 & 0,120 \\
\hline & & $\mathrm{AK}$ & $-0,058$ & 0,019 & $0,002^{*}$ \\
\hline & & GAR & $-0,021$ & 0,015 & 0,164 \\
\hline & GAR & YKB & $-0,001$ & 0,014 & 0,936 \\
\hline & & $\mathrm{AK}$ & $-0,037$ & 0,019 & 0,053 \\
\hline & & ISB & 0,021 & 0,015 & 0,164 \\
\hline
\end{tabular}

$* \mathrm{p}<0,05 . * * \mathrm{p}<0,001$

According to Posthoc Comparisons Results; It was observed that Akbank (APD) card users have a higher awareness than the other bank card users in terms of awareness scores of the products and services offered to them, and that other bank card users did not have any significant superiority or lack in this sense of awareness.

In terms of Using Scores, it may be considered that Akbank credit card users took advantage of using the more products and services available, compare to İş Bankası card users, but the other bank card customers did not have any superiority or deficiency in virtue of using such products and services.

\subsection{Logistic Regression Analysis}

There are three methods used to assign Observations to the possible groups in the structure of the data: Cluster Analysis, Discriminant Analysis and Logistic Regression Analysis. While the number of groups is known in Discriminant Analysis and Logistic Regression, the number of groups is not clear in the Cluster Analysis.

Using the available data in Logistic Regression, a discrimination model is obtained, and it may be possible to assign the new observations, added to the data set, to groups with the help of this model established (Coşkun, Kartal, Coşkun \& Bircan, 2004). However, both due to constraints in data structures and lack of not having the conditions of a normal distribution and the common variance-covariance matrix, application of Discriminant and Cluster Analysis is not possible.

In social sciences, especially in socio-economic researchers in particular, some of the variables studied are measured with precision scale, although some of them contains the binary data set such as "yes/no", "knows/does no know". The binary data are the most commonly used form of categorical data. If the dependent variable is categorical data with binary data, logistic regression analysis is used while examining the cause-and-effect relationship between the dependent and independent variable (or variables) (Agresti, 2007).

Furthermore, the interest in this method increases due to the reasons such as there exists no constraint considering that the independent variables are categorical or continuous; As there is no requirement to provide the assumption of normality of dependent variable; As the model is highly flexible and easy to interpret mathematical (Press \& Wilson, 1978; Tatlidil, 2002). 
The main purpose of Logistic Regression Analysis is to examine the causal relationship between the independent variables and the dependent variable as in other regression methods. In other words to say, the objective is to establish the acceptable model defining the relationship between the least variable and the outcome variable, and the explanatory variables (Aktaş \& Erkuş, 2009; Burmaoğlu, Oktay \& Özen, 2009).

In the study, logistic regression analysis was performed in order to investigate the effects of categorical and numerical independent variable created on categorical and binary structure. The impact of independent variables on the products and services offered by banks to credit card users was investigated using a model established in awareness. In other words to state, the impact of independent variables on the awareness in terms of the products and services offered to credit card users was investigated. Its impact on the use was not taken into consideration as the model is not descriptive (due to the fact that there are many people who use them).

In this context, awareness scores of card users, stated earlier, were taken into consideration. The dependent variable was produced by requiring that the card users are deemed to know at least $50 \%$ of all products and services in order to be aware of a product or service. Accordingly, the card users with an awareness score of $\geq 0,50$ (aware $=1$ ) was coded "aware" while the card users with an awareness score of $<0,50$ (unaware $=1$ ) was coded "unaware" of these products and services.

While the dependent variable to be used in the Logistic Regression Model established for awareness was coded as " $y$ "; " 0 " as "not aware", and "1" as "aware", the independent variables which are thought to have an impact on awareness are:

BANK: the bank, the credit card belongs to, was encoded in the form as follows: $(1=\mathrm{YKB}, 2=\mathrm{AKD}, 3=\mathrm{ISB}$, $4=\mathrm{GAR})$;

GEN: Gender was encoded in the form as follows: $(1=$ Female, $2=$ Male $)$;

MRTSTA: Marital Status was encoded in the form as follows: $(1=$ single, $2=$ married $)$;

EDUC: Education level was encoded in the form as follows: $(1=$ secondary school, $2=$ high school or equivalent, 3 = Vocational school, $4=$ college, $5=$ Graduate);

INCOME: Income was encoded in the form as follows: $(1=1,000 \mathrm{TL}$ and less; $2=1001-2000 \mathrm{TL} ; 3=2001-3000$ TL; 4=3001-5000 TL; 5=5001 TL and above);

AGE: Age was encoded in the form as follows: $(1=24$ years and under; $2=25-34 ; 3=45-54 ; 4=55-64 ; 5=65$ years and over);

DURATION: card usage period, measured in years, was encoded in the form as follows: $(1=1$ year and less; $2=2-5$ years; $3=6-10$ years; $4=10$ years or more) ;

SPEND: the card spending amount, measured in terms of the amount, was encoded in the form as follows: ( $1=250 \mathrm{TL}$ and less; $2=501-750 \mathrm{TL} ; 3=751-1000 \mathrm{TL} ; 4=1001$ and above).

Step by step selection (enter), is a combination of forward and backward selection methods. Logistic Regression starts when there is no variable in the equation, and then a variable is added or subtracted at each step (Ürük, 2007). The results of the logistic regression model obtained by this method are given in the following table.

Table 5. The results of the logistic regression analysis related to AWARENESS model

\begin{tabular}{|c|c|c|c|c|c|c|c|c|}
\hline \multirow{2}{*}{ Variables } & \multirow{2}{*}{ B } & \multirow{2}{*}{ S.E. } & \multirow{2}{*}{ Wald } & \multirow{2}{*}{ df } & \multirow{2}{*}{ Sig. } & \multirow{2}{*}{$\operatorname{Exp}(B)$} & \multicolumn{2}{|c|}{ 95.0\% C.I.for EXP(B) } \\
\hline & & & & & & & Lower & Upper \\
\hline GEN (1) & 0,496 & 0,292 & 2,883 & 1 & 0,090 & 1,641 & 0,926 & 2,908 \\
\hline MRTSTA(1) & 0,271 & 0,323 & 0,707 & 1 & 0,401 & 1,312 & 0,697 & 2,469 \\
\hline INC & & & 16,387 & 4 & 0,003 & & & \\
\hline $\operatorname{INC}(1)$ & 1,758 & 0,988 & 3,167 & 1 & 0,075 & 5,799 & 0,837 & 40,177 \\
\hline $\operatorname{INC}(2)$ & $-1,212$ & 0,606 & 4,001 & 1 & 0,045 & 0,298 & 0,091 & 0,976 \\
\hline $\operatorname{INC}(3)$ & $-0,957$ & 0,501 & 3,647 & 1 & 0,056 & 0,384 & 0,144 & 1,025 \\
\hline $\mathrm{INC}(4)$ & $-1,081$ & 0,483 & 4,999 & 1 & 0,025 & 0,339 & 0,132 & 0,875 \\
\hline AGE & & & 6,158 & 5 & 0,291 & & & \\
\hline AGE(1) & 20,017 & 23205,123 & 0,000 & 1 & 0,999 & 493593370,254 & 0,000 & \\
\hline $\operatorname{AGE}(2)$ & 21,808 & 23205,123 & 0,000 & 1 & 0,999 & 2959304944,242 & 0,000 & \\
\hline $\operatorname{AGE}(3)$ & 21,314 & 23205,123 & 0,000 & 1 & 0,999 & 1804724164,697 & 0,000 & \\
\hline $\operatorname{AGE}(4)$ & 21,373 & 23205,123 & 0,000 & 1 & ,999 & 1915811164,342 & 0,000 & \\
\hline
\end{tabular}




\begin{tabular}{|c|c|c|c|c|c|c|c|c|}
\hline $\operatorname{AGE}(5)$ & 1,362 & 27672,751 & 0,000 & 1 & 1,000 & 3,903 & 0,000 & \\
\hline EDUC & & & 1,286 & 3 & 0,732 & & & \\
\hline EDUC(1) & $-21,401$ & 10504,899 & 0,000 & 1 & 0,998 & 0,000 & 0,000 & \\
\hline EDUC(2) & $-0,911$ & 0,805 & 1,280 & 1 & 0,258 & 0,402 & 0,083 & 1,948 \\
\hline EDUC(3) & $-0,092$ & 0,278 & 0,108 & 1 & 0,742 & 0,912 & 0,529 & 1,575 \\
\hline DURATION & 0,500 & 0,146 & 11,790 & 1 & 0,001 & 1,648 & 1,239 & 2,192 \\
\hline AMOUNT & 0,469 & 0,113 & 17,125 & 1 & 0,000 & 1,598 & 1,280 & 1,996 \\
\hline BANK & & & 14,287 & 3 & 0,003 & & & \\
\hline BANK(1) & $-0,480$ & 0,322 & 2,219 & 1 & 0,136 & 0,619 & 0,329 & 1,164 \\
\hline $\mathrm{BANK}(2)$ & 1,033 & 0,411 & 6,322 & 1 & 0,012 & 2,811 & 1,256 & 6,290 \\
\hline BANK(3) & $-0,058$ & 0,348 & 0,028 & 1 & 0,868 & 0,944 & 0,477 & 1,865 \\
\hline CONSTANT & $-24,391$ & 23205,123 & 0,000 & 1 & 0,999 & 0,000 & & \\
\hline
\end{tabular}

* : significant at \% 1 significance level, **: significant at \% 10 significance level.

The Wald value in the Logistic Regression Analysis is an assessment criterion for variables, as well. This value is considered to be significant for values greater than 2 (Coşkun, et al., 2004). When the significance of parameters was considered in the model, INC, DURATION, AMOUNT, and BANK independent variables were significant at $1 \%$ level, GEN variable was significant at the level of $10 \%$. It may be stated that MRTSTA, EDUC, AGE variable parameters have no input in explaining the dependent variable.

Logistic Models, where multiple independent variables exist, are similar to other multivariate regression models, while the interpretation of the coefficients is different depending on the type of independent variable (Agresti, 2007). The value of the dependent variable is predicted in Linear Regression Analysis while the probability of occurrence of one of the values of the dependent variable is predicted in Logistic Regression (Coskun et al, 2004). Effects in Logistic Model are based on Odds. The ratio of Odds estimated in an X value is given as the ratio of Odds estimated in another $\mathrm{X}$ value. This statistic gives the result how many times more the dependent variable of individuals with $(X=1)$ is considered than that of individuals with $(X=0)$ (Bircan, 2004).

According to the ratio of Odds (Exp (B)), it may be stated that the possibility of awareness of women compared to men in terms of services for card products will be about 1,641 times more. It was observed that the possibility of awareness in low-income groups is more likely; $1 \%$ increase in card usage period will affect the possibility of awareness 1,648 times more. $1 \%$ increase in card spending amount will affect the possibility of awareness 1,598 times more. On account of card users, Akbank card users have the highest level of awareness $(2,811)$, which was also determined by the LSD test conducted.

The difference of parameters from zero is tested by Omnibus Test which examines the significance of the model. According to the hypothesis established as $H_{0}: \beta_{0}=\beta_{1}=\beta_{2}=\ldots=\beta_{k}=0$ ve $H_{1}: \beta_{0} \neq \beta_{1} \neq \beta_{2} \neq \ldots \neq \beta_{k} \neq 0$ (at least one of them is different), the Omnibus test result is given in Table 6 below. Also, as the G statistic (430.532), degrees of freedom 8 , significance level $5 \%, \chi^{2}$, are bigger than $\chi^{2}$ table value (15.507), the null hypothesis is rejected. Logistic regression coefficients are not equal to zero at the same time, so the model may be stated to be statistically significant at 5\% level.

Table 6. Omnibus tests of model coefficients

\begin{tabular}{lcccc}
\hline & & Chi-square & df & Sig. \\
\hline Step 1 & Step & 87,782 & 19 & 0,0001 \\
& Block & 87,782 & 19 & 0,0001 \\
& Model & 87,782 & 19 & 0,0001 \\
\hline
\end{tabular}

Table 7. Hosmer and Lemeshow test

\begin{tabular}{lrrc}
\hline Step & Chi-square & df & Sig. \\
\hline 1 & 6,447 & 8 & 0,597 \\
\hline
\end{tabular}

After Logistic Regression Model is estimated by any estimation technique, the goodness-of-fit of the established model should be tested. It is need to know how effective the dependent variable is defined. To do this, the 
goodness-of-fit of the model should be checked. The Hosmer-Lemeshow (HL) test which is suitable, to chi-square distribution may be used in the checking the consistency of Goodness-of-fit of the logistic model. The goodness-of-fit of the model, which shows how effective the dependent variable was defined, exposes, according to the conclusion reached, that dependent variable is defined in an effective manner (Murat \& Işı̆ı̆ıçok, 2007).

After the hypothesis to be test by Hosmer-Lemeshow (HL) Test which is used in order to test the goodness-of-fit of the model; It was seen that $\chi^{2}=6,447$, 8 (d.f.), $\mathrm{p}=0,597$. As $\mathrm{P}$ value is $(0,597)>0,05$, it is possible to say that $H_{0}$ hypothesis can not be denied. It would be beneficial to check the classification table, which is significant in terms of the goodness-of-fit, as well.

According to Table 8, it was observed that the true estimate rate of the status of unawareness of the card users about products and services offered to them, was $86 \%$, the prediction rate of the status of being aware was 48,9 (\%). It was observed that the overall correct classification rate of the model seems to be $72,9 \%$.

Table 8. Classification chart

\begin{tabular}{|c|c|c|c|c|}
\hline \multirow[t]{3}{*}{ Observed } & & \multicolumn{3}{|c|}{ Predicted } \\
\hline & & \multicolumn{2}{|c|}{ Awareness } & \multirow{2}{*}{$\begin{array}{l}\text { Percentage } \\
\text { Correct }(\%)\end{array}$} \\
\hline & & 0 & 1 & \\
\hline \multirow[t]{2}{*}{ Awareness } & 0 & 222 & 36 & 86,0 \\
\hline & 1 & 72 & 69 & 48,9 \\
\hline \multicolumn{4}{|c|}{ Overall Percentage(\%) } & 72,9 \\
\hline
\end{tabular}

\subsection{Hypothesis Results}

Of the established research hypotheses, it was observed that $H_{1}, H_{2}, H_{3}, H_{6}, H_{8}$ and $H_{9}$ are the supported hypotheses; while $H_{4}, H_{5}$ and $H_{7}$ hypotheses were not supported. Accordingly, we may say, with hypothesis $H_{l}$, that credit card users' awareness for the products and services offered by their banks is different in terms of banks; and with hypothesis $H_{2}$, that the rate of use by credit card users of the products and services offered by their banks is different in terms of banks.

Furthermore, observing the established Logistic Regression Model, it was determined, with the hypothesis $H_{3}$, that gender variable has an effect on the awareness at $10 \%$ margin of error; and with the hypotheses $H_{6}$, $H_{8}$, and $H_{9}$ respectively, the income variable, the duration of use, the card spending amount, have an effect on the awareness at $1 \%$ margin of error. On the other hand, it was observed that with the hypotheses $\mathrm{H} 4, \mathrm{H} 5$ ve $\mathrm{H} 7$ respectively, marital status, education level and age had no effect in terms of products and services offered along with credit cards.

\section{Discussion}

With the help of the results obtained in this study, we aimed to draw attention to the awareness and use of the products and services of the credit card users in Turkey.

It was observed that the most valuable service to create awareness in terms of products was "to take advantage of discount programs offered along with your credit card for the use of certain products and services", and that this is the service noticed firstly by the entire bank card customers. It was also observed that the highest rate of awareness (83\%) of this service was of the customers of Garanti Bank. However, according to this data, services that provide awareness at the lowest rate were "Sea Taxi Service", "Bodyguard Security Package Service" and "Glass Breakage Assistance".

In terms of the level of use of the products and services offered, "to take advantage of discount programs offered along with your credit card for the use of certain products and services" and "card interruption and property", were the services with the highest level of use. On the other hand, the services with the lowest level of use among the card users of products and services were the services for Garanti Bank card users, and those services were "Glass Breakage Assistance", "Road Assistance", "Locksmith Assistance" and " Plumber Assistance" services.

One-way ANOVA test was applied in order to compare the scores of awareness and use of bank cards in terms of products and services offered for bank card users. It was determined that both the scores of awareness and the rate of use were different at 5\% margin of error, and Posthoc was applied due to this case. Accordingly, while, in terms of awareness scores, determined that the awareness scores of Akbank card users were higher than that 
of other bank card users, it was observed that other bank card users did not have any relative superiority or lack over each other in this sense of awareness.

In terms of use scores, it may be considered that Akbank card users took advantage of card products and services more than İş Bank card users did; and that other bank card users did not have any relative superiority or lack over each other in this sense of use of such products and services.

It was determined that Logistic Regression Model, established for the awareness of products and services of the credit card users, was determining and significant in general; that GEN (gender) variable, in terms of awareness of products and services, was significant at $10 \%$ margin of error (Any extra t-test was not applied for the difference between means).

In addition, it was determined that the independent variables of INC, DURATION, BANK, and AMOUNT are effective on the dependent variables at the level of 1\%; However, MRTSTA, EDUC, AGE variables were not significant enough so as to enter this model. Test results obtained by One-way ANOVA was also supported by Logistic Regression Model.

\section{Conclusions}

The rate of product development and differentiation is observed to have reached a strategic level due to the changing dimensions of competition in the race of the businesses, sectors, and even the countries with each other.

One of the most valuable tools of card providing banks, in order to expand the credit card market, and to increase the amount of spending, is to promote this kind of products and services offered to credit card users, and to make them use these cards more effectively, by making them more privileged. One of the most vital tools for this is to increase the promotion of such products and services.

The innovative behavior of the banks for the current brand/product/service and their strategies for differentiation of these products and services, do not only affect your buying decision, but they also support the development of consumer awareness. Banks, who want to impact their customers' purchase decisions in a positive way, are observed to be adopting themselves to use of integrated marketing communication more efficiently, by understanding the changing sociopsychological structure of the consumers.

Considering the results of the study, it was determined that awareness, in terms of the products and services offered by the banks, was higher at the discount programs. In terms of levels of use, that some of the bank card users have never used some of the products and services offered by the banks. It may be expressed that the consumers actively using these products/services are those who are more conscious about the products/services, purchasing by a credit card, holding the card for a longer time, and those who make a higher amount of spending.

This fact draws the attention to the thought that some enterprises do not inform their consumers or potential card users about the innovations and differentiations in card services, although they identify and use more detailed information about the consumer in the process of restructuring the card services more carefully.

This case may be assessed in two ways: the first is that the banks do not publicize their credit card applications effectively through integrated marketing communications (due to the fact that they avoid extra service costs), and the other may be due to the fact that banks' innovative attitudes aim to make more new customers.

For instance, as a credit card brand helps one of his customers who had his car breaks down on the way, the customer will adopt this credit card brand more further. He will use this card more often; this will increase his confidence for this card, and most importantly, this will help to make him to be a loyal customer of the card brand with the satisfaction of having this particular credit card.

Intense competition in the credit card market has guided banks to add loyalty programs to the credit cards with new features, such as the target points, money-back programs, community card programs, and locksmith, programs. Similarly, a lounge service offered to card customer at the airport will lead to an increase in the prestige of the card holder, and this will meet the customer satisfaction. The only goal of the bank, which preserves the customer satisfaction by offering such a service to meet the needs of its customer, should not be just a competition with the other rival banks. Banks must clear express the message, with the help of these types of products and services that they are always next to their cardholders, and will always support him when needed. 
Placing a successful, and a positive and long-term corporate/brand image into the minds of consumers means to access the successful potential benefits of purchasing and card use. This is possible with a well-integrated, interactive, synergy creating marketing mix, and integrated marketing communication..

The most significant result obtained in this study is that it seems to be the first study conducted in this field. In this regard, what is expected is that it will contribute the other works in this field, in terms of marketing activities, by ensuring to provide conceptual integrity while evaluating the credit cards with other products and services offered along with it.

It is highly possible that the products and services offered along with the credit cards in these markets will be further developed in other countries, due to the development of credit cards market and the increased competition in the market and that they will be the products and services which are not only supporting the brand, but also dragging it.

\section{Limitations and Future Research}

The current research has several limitations:

First: In this study, the most well known credit card brands were taken into account, and a number of conclusions were reached. More accurate results can be obtained with the expansion of the study to include all credit card users.

Second: If the number of samples in terms of Awareness and Use taken into account in this study are increased, more accurate results will be reached.

Third: The demographic variables such as Age, Income, Education, Marital Status, have not been compared to the levels of awareness and use in this study, so as not to take up too much space.

Fourth: This study is the first study in this area, and we tried to draw attention to the awareness and use of products and services offered to card users. In the Logistic regression model established for this purpose, the model was developed by considering the variables expected to be the most effective ones; more accurate models can be installed by increasing the number of variables.

\section{References}

Aaker, D. A. (1991). Managing Brand Equity. NY: Free Press.

Agresti, A. (2007). An Introduction To Categorical Data Analysis. Wiley-Interscience. Retrieved from http://www.Google.Com/Books?Hl=Tr\&Lr=\&İd=Gcskkczwjyic\&Oi=Fnd\&Pgn=Pr5\&Dq=An+Introductio $\mathrm{n}+\mathrm{To}+$ Categorical + Data + Analysis $+1996 \& O t s=5$ luyb6nai8\&Sig=Qp5oynvwjxnv2cqz2vuxlfmwyn4

Aktaş, C., \& Erkuş, O. (2009). Lojistik Regresyon Analizi İle Eskişehir'in Sis Kestiriminin İncelenmesi. İstanbul Ticaret Üniversitesi Fen Bilimleri Dergisi, 8(16), 47-59.

Aktuğlu, I. K. (2004). Marka Yönetimi. İletişim Yayınları, İstanbul.

Aktuğlu, K. I., \& Temel, A. (2006). Markalar Nasıl Tercih Ediliyor? (Kamu Sektörü Çalışanlarının Giysi Markalarını Tercihini Etkileyen Faktörlere Yönelik Bir Araştırma. Konya Selçuk Üniversitesi Sosyal Bilimler Enstitüsü Dergisi, 15.

Bircan, H. (2004). Lojistik Regresyon Analizi: Tıp Verileri Üzerine Bir Uygulama. Kocaeli Üniversitesi Sosyal Bilimler Enstitüsü Dergisi, 2, 185-208. Retrieved from http://kosbed.kocaeli.edu.tr/sayi8/bircan.pdf

Burmaoğlu, S., Oktay, E., \& Özen, Ü. (2009). Birleşmiş Milletler Kalkınma Programı Beşeri Kalkınma Endeksi Verilerini Kullanarak Diskriminant Analizi ve Lojistik Regresyon Analizinin Sinfflandırma Performanslarının Karşılaştırılması. Savunma Bilimleri Dergisi, 8(2), 23-49.

Cengiz, E. (2009). Bireylerin kredi kartlarını değiştirme tutumları. Firat Üniversitesi Sosyal Bilimler Dergisi, 19(2), 179-196.

Cooper, G. R., Edgett, J. S., \& Kleinschmidt, E. J. (2003). Improving New Product Development Performance and Practices. American Productivity \& Quality Center-APQC, USA.

Coşkun, S., Kartal, M., Coşkun, A., \& Bircan, H. (2004). Lojistik Regresyon Analizinin İncelenmesi Ve Diş Hekimliğinde Bir Uygulaması. Cumhuriyet Üniversitesi Diş Hekimliği Fakültesi Dergisi, 7(1). Retrieved From http://Eskidergi.Cumhuriyet.Edu.Tr/Makale/958.Pdf

Diehr, P., \& Lumley, T. (2002). The Importance of The Normality Assumption in Large Public Health Data Sets. Annu Rev Public Health, 23, 151-169. Retrieved from http://works.bepress.com/paula_diehr/24/ 
Durukan, T., \& Elibol, H., \& Özhavzalı, M. (2005). Kredi Kartlarındaki Taksit Uygulamasının Tüketicinin Harcama Alışkanlıkları Üzerindeki Etkisini Ölçmeye Yönelik Bir Araştırma (Kırıkkale İli Örneği). Selçuk Üniversitesi Sosyal Bilimler Enstitüsü Dergisi, 13, 143-155.

Elitok, B. (2003). Hadi Markalaşalım. Sistem Yayıncılık, İstanbul.

Gökçen, G., \& Kaya, F. (2009). Bireysel müşterilerin kredi kartı tercihlerine etki eden faktörlerin belirlenmesi. Bankacular Dergisi, 20(70), 3-17. http://dx.doi.org/10.11122/ijmeb.2013.9.19.335

Hyytinen, A., \& Takalo, T. (2008). Consumer awareness and the use of payment media: Evidence from young Finnish consumers. Bank of Finland Research Discussion Papers, 2, 3-33.

Johansson, G. (2002). Success Factors for Integration of Eco-Design in Product Development. Environmental Management and Health, 13(1), 104-115.

Karacan, D. (2006). Müşteri Odaklı Marka Denkliği ve Marka Denkliği Unsurlarına Yönelik Tüketici Tutumlarının Ölçülmesi: Otel İsletmeleri Üzerine Bir Uygulama. Çukurova Üniversitesi, Sosyal Bilimler Enstitüsü Yüksek Lisans Tezi, Adana.

Kim, H., \& De Vaney, S. A. (2001). The determinants of outstanding balances among credit card revolvers. Financial Counseling and Planning, 12(1), 67-79.

Koç, E. (2012). Tüketici Davranışı ve Pazarlama Stratejileri. Seçkin Yayınevi, Ankara.

Kovanc1, A. (2004). Toplam Kalite Yönetimi. Sistem Yayınc1lık, İstanbul.

LaTour, K., LaTour, M. S., \& Zinkhan, G. M. (2010). Coke is It: How stories in childhood memories illuminate an icon. Journal of Business Research, 63(3), 328-336.

Leblebici, H. (2009). Marka Görsel Kimliği Unsurlarından Logoya Yönelik Tüketici Algıların Belirleme Üzerine Bir Çalış̧a. Çukurova Üniversitesi Sosyal Bilimler Enstitüsü İşletme Anabilim Dalı Yüksek Lisans Tezi, Adana.

Mucuk, İ. (2001). Pazarlama İlkeleri. Türkmen Kitabevi, İstanbul.

Murat, D., \& Işı̆̆ıçok, E. (2007). 2007 Seçim Döneminde Ekonomik ve Siyasi Duruma İlişkin Beklentiler: Bursa Uygulaması. Retrieved from http://Web.İnonu.Edu.Tr/ Eisemp8/Bildiri-Pdf/Murat-İsigicok.Pdf

Norvilitis, J. M., Osberg, T. M., Young, P., Merwin, M. M., Roehling, P. V., \& Kamas, M. M. (2006). Personality factors, money attitudes, financial knowledge and credit-card debt in college students. Journal of Applied Social Psychology, 36(6), 1395-1413.

Odabaşı, Y., \& Barış, G. (2003). Tüketici Davranışı, Kapital Medya Hizmetleri. İstanbul.

Odabaşı, Y., \& Oyman, M. (2007). Pazarlama İletişimi Yönetimi. MediaCat Yayınları, İstanbul.

Özdamar, K. (1999). Paket Programlar İle İstatiksel Veri Analizi: Spss-Minitab (Çok Değişkenli Analizler). Eskisehir: Kaan Kitabevi.

Press, S. J., \& Wilson, S. (1978). Choosing Between Logistic Regression and Discriminant Analysis. Journal Of The American Statistical Association, 73(364), 699-705. http://www.doi/10.1080/01621459.1978.10480080

Savaş̧ı, İ., \& Tatlıdil, R. (2006). Bankaların Kredi Kartı Pazarında Uyguladıkları CRM(Müşteri İlişsileri Yönetimi) Stratejisinin Müşteri Sadakatine Etkisi. Ege Akademik Baklş, 6(1), 62-73.

Schiffmann, L. G., \& Kanuk, L. L. (2007). Consumer Behavior (9th ed.). Upper Saddle River, NJ: Prentice Hall.

Tatlıdil, H. (2002). Uygulamalı Çok Değişkenli İstatistiksel Analiz. Ankara: Ziraat Matbaacılık.

Torlak, O. (2002). Kredi Kartı Kullanımının Satın alma Alışkanlıklarına Etkileri Üzerine Eskişehir'de Bir Araştırma. Yönetim, 13(41), 67-78.

Tunalı, H. F., \& Taloğlu, Y. (2010). Factors affecting credit card uses: Evidence from Turkey using Tobit model. Europen Journal of Economics, Finance and Administrative Sciences, 23, 81-101.

Ucal, M., Lou O’Neil, M. \& Çankaya, S. (2011). Effects of gender on credit card usage among university students in Turkey. African Journal of Business Management, 5(22), 9023-9030.

Ürük, E. (2007). Istatistiksel Uygulamalarda Lojistik Regresyon Analizi, T. C. Marmara Üniversitesi Fen Bilimleri Enstitüsü (Yüksek Lisans Tezi), İstanbul. 
Yaraş, E. (2005). Tüketicilerin Pazarlama Karması Kararları ve Marka Değeri Algılamalarına Göre Kümeler Halinde İncelenmesi. Atatürk Üniversitesi İktisadi ve İdari Bilimler Fakültesi Dergisi, 19(2), 349-372.

Yayla, Y., \& Yıldız, A., \& Akyüz, B. (2009). İşletmenin Örgütsel Özellikleri İle Ürün Geliştirme Ekiplerinin Başarısı Arasındaki İlişkinin İncelenmesi: Seramik Sektöründe Bir Saha Araştırması. İstanbul Ticaret Üniversitesi Fen Bilimleri Dergisi, 8(16), 13-30.

Yeniçeri, T., \& Akturan, U. (2007). Kredi kartını bilinçli kullanan ve kullanmayan tüketicileri ayırmada kullanılabilecek temel belirleyiciler üzerine bir pilot araştırma. Hacettepe Üniversitesi İktisadi ve İdari Bilimler Fakültesi Dergisi, 25(2), 243-266.

Yılmaz, H., Budak, G. S., \& Başaran, B. (2013). Kredi Kartı Kullanım Alışkanlıklarında Kategorik Değişkenler Arasındaki İlişskiler Ve Bireylerin Davranışsal Eğilimleri: Bilecik Örneği. Int. Journal of Management Economics and Business, 9(19), 31-49.

Yükselen, C. (2012). Pazarlama, Illkeler-Yönetim-Örnek Olaylar. Detay Yayıncılık, Ankara.

Zaltman, G. (2003). Tüketici Nasıl Düşünür? Çeviren: A.Semih Koç. Media Cat Kitapları, İstanbul.

\section{Copyrights}

Copyright for this article is retained by the author(s), with first publication rights granted to the journal.

This is an open-access article distributed under the terms and conditions of the Creative Commons Attribution license (http://creativecommons.org/licenses/by/3.0/). 